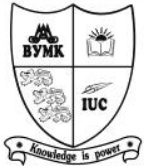

European Journal of Tourism Research

http://ejtr.vumk.eu

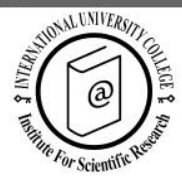

\title{
Testing the relationship between product innovation and process innovation. A comparative analysis of tourism and manufacturing sectors
}

\author{
Manuel Guisado-González ${ }^{1}$, Manuel Guisado-Tato ${ }^{1 *}$ and \\ Maria del Mar Rodríguez-Domínguez ${ }^{1}$
}

Received: 22/11/2013 Accepted: 18/05/2014

\begin{abstract}
1 Universidad de Vigo, Facultad de Ciencias Económicas y Empresariales, Departament: Business Administration, Campus de Vigo, 36310 Vigo, Spain, Phone: +34 986 812487, Fax: +34986812401, Email: mguisado@uvigo.es

* Corresponding author
\end{abstract}

\section{Abstract}

Innovation is a key issue for business competitiveness. The most popular kinds of innovation are product innovation and process innovation. The effect of both types of innovation within a company is seen in the specialist literature from two opposing views: the distinctive view, which considers that both kinds of innovation are independent, and the integrative view, which assumes the existence of complementarities between the two kinds of innovation. The aim of this paper is to explore which of the two approaches dominates the context of both the tourism sector and the Spanish manufacturing sector. With samples taken from the database of the Technological Innovation Panel (PITEC 2008), two binary logistic regressions were conducted in two stages and a correlation test was performed with their residuals. The results show that each of the two types of innovation is independent.

(C) 2014 International University College. All rights reserved

Keywords: Coexistence, product innovation, process innovation, tourism sector, manufacturing sector

Citation: Guisado-González, M., M. Guisado-Tato, M. Rodríguez-Domínguez (2014) Testing the relationship between product innovation and process innovation. A comparative analysis of tourism and manufacturing sectors. European Journal of Tourism Research 8, pp. 66-82

\section{Introduction}

The global tourism sector has acquired a structural importance for the economies of both developed countries and developing countries (Ivanov \& Webster, 2013). According to the
World Tourism Organization, tourism revenues account for $6 \%$ of total world export of goods and services and $30 \%$ of total world export of services (WTO, 2012). These figures speak for themselves about the structural importance of 
tourism and its capacity to generate added value and employment.

Furthermore, it is worth noting that, like many other sectors, tourism is undergoing a process of increasing technological change (Ritchie \& Crouch, 2000; Hjalager, 2002). This change took place mainly as a result of the information technology revolution in the 1980s. Such a revolution prompted changes in the concept of innovation and facilitated the visibility of tourism as an innovative sector (Hjalager, 2010).

Therefore, at present, in order to improve the competitiveness of tourism companies, it is necessary to understand the sources and patterns of innovation activities, primarily those that are directly attributable to tourism (Hjalager, 2013). However, several authors note that studies of innovation in tourism are scarce (Aldebert, Dang, \& Longhi, 2011; Alsos, Eide, \& Madsen, 2014; Camisón \& Monfort-Mir, 2012; Drejer, 2004; Flikkema, Jansen, \& Van der Sluis, 2007; Hjalager, 2002; Pechlaner, Reuter, \& Zehrer, 2010; Sundbo, Orfila-Sintes, \& Sorensen, 2007; Weiermair \& Peters, 2002). Indeed, to counteract at least partially, the shortage of empirical studies about innovation in tourism, this study aims to provide new insights into two of the recurring debates in the field of innovation: firstly, in the context of the Spanish tourism sector, an analysis will be undertaken of the possible coexistence or substitutability relationship between product and process innovation; secondly, the study will compare these relationships with those that take place in the Spanish manufacturing sector in order to test empirically whether innovation behaviours in tourism and manufacturing companies are quite different (e.g. Hjalager, 2002, Volo, 2004).

The coexistence of both types of innovation has not been analysed for the tourism sector. In other sectors, mainly in manufacturing, the mutual relations of causality between product innovation and process innovation have been studied (Fritsch \& Meschede, 2001; Kraft, 1990; Martinez-Ros, 2000; Salter \& Alexy, 2014), as well as coexistence relations, through correlation coefficients (Damanpour \& Gopalakrishnan, 2001; Zahra, Neubaum, \& Huse, 2000). Moreover, the relationship of complementarity between different innovation strategies, such as 'make', 'buy' or 'cooperate', has been studied (e.g. Cassiman \& Veugelers, 2006; Schmiedeberg, 2008). Also, in the specific area of the hospitality industry, studies have been carried out analysing the coexistence between a set of innovation strategies in which they break down each of the aforementioned strategies (Guisado-González, Guisado-Tato, \& Sandoval, 2013).

The relationship between product innovation and process innovation has been analysed in the economic literature from two opposing views (Damanpour, 2010): on the one hand, there is the distinctive view, which considers that both types of innovation are independent; on the other hand, there is the integrative view, which assumes that both types of innovation are complementary.

In the distinctive view, the studies which have attempted to investigate the causes that are critical to each of the two types of innovation have carried out such research separately (Damanpour, 2010), considering first one kind of innovation and then the other (e.g. Baer and Frese, 2003; Li and Atuagene-Gima, 2001). However, subsequent schools of thought have emerged, advocating the need for studies that aim to analyse the generation or joint adoption of both types of innovation, because companies that simultaneously introduce product and process innovations are more likely to achieve better performance measures (e.g.. Fritsch and Meschede, 2001; MartinezRos, 2000). Such studies fall within the orbit of the integrative view.

Nonetheless, before proceeding to the simultaneous analysis of both types of innovation and testing whether their joint action on performance is greater than the sum of their separate influences, it is advisable to evaluate whether both innovations coexist, are alternatives to each other or have no statistical influence on each other. In precise terms, acquiring evidence about the kind of relationship between both types of innovation is the main objective of this study. Indeed, the aim is to understand the kind of relationship that maintains both types of innovation.

The remaining structure of this paper is organised as follows: section two briefly 
Testing the relationship between product innovation and process innovation. A comparative analysis of tourism and manufacturing sectors.

presents some of the main contributions to the analysis of the relationship between product and process innovation, as well as the objectives of the current empirical study. Section three is a theoretical analysis of coexistence, while section four provides the data, models, and the research methodology. In section five, the results are reported and discussed, and the conclusions are presented in section six.

\section{The interaction between product and process innovation}

Nowadays, it is widely accepted that the ability to innovate is key to increasing the market share of companies, entering new markets and achieving and sustaining one or more competitive advantages (Hitt, Ireland, Camp, \& Sexton, 2001; Hult, Snow, \& Kandemir, 2003; McAdam \& Keogh, 2004; Tether, 2014; Tether \& Howells, 2007).

In the manufacturing sector, there are numerous studies that have contributed to the development of different types of innovation. As research on innovation in the tourism sector started much later, there are not many contributions on different types of innovation in this sector (e.g. Weiermair, 2006; Hjalager, 2002; Hall \& Williams, 2008; Hjalager, 2010). In the available literature, product innovation and process innovation can be found explicitly, but it is also possible to find next to them other types of innovation. Product innovation refers to the creation of new or improved goods and services, and process innovation refers to the way these goods and services are produced (Fagerberg, 2005, Walker, 2004). The European Community Innovation Surveys (CIS) also use this typology (Drejer, 2004). The current empirical uses the Spanish version of the CIS.

In general, the literature on innovation has adopted the distinctive version, i.e. the one that states that both types of innovation are influenced by different variables (Baldwin, Panel, \& Sabourin, 2002; Fritsch \& Meschede, 2001) and that they have a different impact on the innovation performance of firms (Damanpour, Szabat, \& Evan, 1989). This is probably due to the influence of two major streams of thought on innovation studies: a) the product life-cycle model (Abernathy \& Utterback, 1978), which states that, at each stage of the life cycle, only one type of innovation dominates (product innovation or process innovation).

b) the view that companies should not try to position themselves simultaneously in terms of differentiation and cost leadership (Porter, 1985) - generally, relating product innovation to the differentiation strategy and process innovation to the cost leadership strategy. For example, there are many studies that relate product innovation to the demand for new products by customers and process innovation to the reduction of operational costs (Schilling, 2005). In addition, other studies relate process innovation to efficiency and product innovation to effectiveness (Subramanian \& Nilakanta, 1996).

Both streams promote separate analysis of the determinants of each of these innovations and their corresponding impact on company performance. For example, the studies by Atuahene-Gima (1996), Subramanian and Nilakanta (1996), Han, Kim and Srivastava (1998), and Li and Atuagene-Gima (2001) have focused exclusively on the analysis of product innovation, while the studies of Marcus (1988), Ittner and Larcker (1997), Whittington et al. (1999), Olson and Schwab (2000), Knott (2001) and Baer and Frese (2003) have focused on process innovation.

Nevertheless, some authors have abandoned the distinctive view of the two types of innovation considered. Thus, Kraft (1990) postulated that both classes of innovation are mutually mediated; therefore, their analysis must be done jointly. However, this author found that product innovation has a positive and significant influence on process innovation, while the reverse influence is negative and not significant. By contrast, Fritsch and Meschede (2001) found that product innovation has a negative influence on process innovation, while the latter has a positive influence on product innovation. Also, Martinez-Ros (2000) found that both types of innovation influence each other in positive and significant ways. Finally, Gunday et al. (2011) explored the causal relationship between process innovation and product innovation and found that process 
innovation has a positive and significant effect on product innovation.

Another group of studies test the mutual relationship between product innovation and process innovation through correlation coefficients. In this regard, Damanpour and Gopalakrishnan (2001), Ettlie and Rubenstein (1987), Gunday et al. (2011) and Zahra et al. (2000), among others, found a positive relationship between both types of innovation. The information on correlation coefficients was provided as additional and complementary information to the main objectives which were pursued in each study, and so a defined methodology for the analysis of coexistence of both types of innovation was not provided.

These first attempts to analyse jointly the two types of innovation are due to the growing belief that research should be positioned around an integrative view, because the performance of companies depends on the joint contribution of both types of innovation, i.e. dependent on the synergistic effect arising from the simultaneous action and not from the action of their respective influences separately (Damanpor, 2009).

This integrative view of product innovation and process innovation is based on the contributions of three different approaches: the resource-based view, absorptive capacity and market orientation.

The resource-based view conceives of each company as a unique set of resources developed throughout its history (Wernerfelt, 1984; Barney, 1991) and takes into account its ability to generate new resources tailored to the demands of its corresponding environment (Teece, 1986; Teece, Pisano, \& Shuen, 1997). This view emphasises that the construction of 'competitive advantage' depends fundamentally on the combination of heterogeneous resources in a unique manner (Wernerfelt, 1984; Barney, 1991; Conner, 1991; Peteraf, 1993). This new approach has stimulated the interest of researchers in so-called 'complementary assets' (e.g. Powell \& DentMicallef, 1997; Somaya, Williamson, \& Zhang, 2007; Adegbesan, 2009), that is, to discover the keys for generating competitive advantage.
Thus, this approach has contributed decisively to focusing on the construction of competitive advantage in achieving synergies that may result from a specific combination of internal resources held by each company, such as the resources and capabilities related to product and process innovation which could be complementary (Teece et al., 1997).

In this vein, the complementarity of resources and capabilities can also be found beyond the walls of each company, inasmuch as other organisations have resources and capabilities that can be complementary to those which are possessed by the company internally. In order to produce synergies between internal and external resources, it is necessary for the company to have the ability to identify and exploit these external resources. Both roles constitute the so-called 'absorptive capacity' (Cohen \& Levinthal, 1989, 1990; Zahra \& George, 2002), which provides firms with a better environmental scan for the search of knowledge, thus simplifying their identification and exploitation (Hagedoorn \& Wang, 2012). This means that companies which have not developed significant absorption capacity through research activities in the domestic sphere will face serious difficulties when they go abroad in search of knowledge, because they will lack the basic tools needed to identify which knowledge is necessary to help them achieve their goals and to discern the most appropriate external source. Since both types of innovation are mutually dependent to some extent, companies need to develop simultaneously a certain degree of absorption of both types of innovation, otherwise they will be unable to identify and exploit product and process innovations existing outside the company that are necessary to complement their internal developments.

The disposition of companies to continuously give customers superior value is the central node of the market-oriented approach (Narver \& Slater, 1990). From this perspective, authors like Bhoovaraghavan, Vasudevan and Chandran (1996) suggest that product innovation and process innovation are necessarily interdependent, because only in this way is it possible to satisfy the needs of customers and improve company performance. 

manufacturing sectors.

Since there are thus two opposing theoretical views regarding product innovation and process innovation (distinctive view versus integrative view), the current study will test which of these two perspectives prevails in the field of tourism. An analysis will be undertaken of whether, in the tourism sector, both classes of innovation coexist, are substitutes for each other, or are independent, with no statistically significant relationship.

It is common to note the existence of significant differences in innovative activity between the service sector and the manufacturing sector (Sundbo, 2007; Pires, Sarkar, \& Carvalho, 2008). These differences are caused by the different peculiarities of the service sector, such as the high degree of heterogeneity of the companies in the tourism sector (Carvalho, 2011) , the simultaneous occurrence of production and consumption, the typical characteristics of tourism (Weiermair, 2006), an abysmal record of organisational innovation to address technological innovation (Hollanders \& Van Cruysen, 2008), the intrinsic difficulty of discerning between product and process innovations (Gronroos, 1990) and, finally, the fact that most of the tourist sector innovations consist of new practices and procedures which are in public view, and so easily imitated by rival firms ${ }^{\mathrm{ii}}$. This gap in the protection of their innovations should become a powerful driver that pushes tourism enterprises to increase their innovative activity, since only through innovation can these companies maintain a highly competitive position (Hjalager, 2002; Hall \& Williams, 2008).

Moreover, Drejer (2004) notes that, while innovation in the service sector and the manufacturing sector is not identical, it cannot be claimed that both kinds of innovation are completely different. Hjalager (2002) also points out that many of the determinants of innovation are common to most sectors, whether the tourism sector or the manufacturing sector.

Therefore, this study will test whether the relationships of coexistence between product and process innovation in the tourism and manufacturing sectors are similar or differ substantially.

\section{The theoretical foundations of coexistence} analysis. The adoption approach.

In the field of strategy and organisational analysis, the term complementarity began to be used in the 1960s and 1970s (e.g. Rothwell, Freeman, Horsley, Jervis, Robertson, \& Townsend, 1974; Rothwell, 1975), although references to the subject were generally vague and imprecise.

Later, in the 1980s, the term complementarity was most commonly used in the field of organisational design literature (Miller \& Friesen, 1984; Miller, 1986). Moreover, Teece (1986) argues that the successful commercialisation of an innovation often requires the employment of co-specialised complementary resources, such as the capacity of post-sale service, specific distribution channels and, in general, marketing expertise.

In the context of an open innovation approach, companies currently go beyond the internal boundaries of their own organisations to build their specific innovation strategies. In this regard, such an approach also indicates that the ability of firms to combine domestic sources of knowledge with external sources is crucial to the construction of competitive advantage (Baptista \& Swan, 1998; Rigby \& Zook, 2002). Consequently, this trend recognises the undoubted existence of complementarities between the different sources of knowledge available to firms.

All the previous references perceive the existence of complementarities between different business activities, and prescribe such complementarities as an invaluable construction source of competitive advantage. However, none of the mentioned streams has developed a technique or methodology to test unequivocally their existence within the company.

But the theoretical foundations that allowed its application in the field of empirical studies had already been developed by Topkis' (1978) 'lattice theory', within which the supermodular functions are defined. Such functions allow a precise formalisation of complementarity conditions between groups of variables. 
Subsequently, Vives (1990) and Milgrom and Roberts (1990) introduced the application of lattice theory in economic analysis; the former introduced it in the analysis of the so-called 'general economy', considering the Nash equilibrium in the context of complementarities of a strategic nature, while the latter introduced the use of supermodular functions in strategic decision-making in the context of a multiproduct company with a flexible manufacturing process. The elegant model presented by Milgrom and Roberts (1990) allows complementarities to be analysed between technological variables, marketing variables, manufacturing variables, production process variables and variables related to design and organisation.

In what follows, the basics of lattice theory will not be explained, since it is beyond the scope of a study of this nature, but it should be noted that this theory makes it possible to affirm that, if two variables are complementary, the adoption of one of them increases the probability of adopting the other, which suggests the existence of a clear positive correlation between them.

Similarly, the so-called revealed preferences theory also suggests that, in the presence of two complementary activities, the company in pursuit of profit maximisation tends to adopt the two activities together or not adopt any, which inevitably leads to the existence of correlation between these activities (Schmiedeberg, 2008).

Determination of the correlation between two variables constitutes a detection method of complementarity, which enjoys high predicament and is widely used. One of its main advantages is that it can be applied to the available information on the activities undertaken by a company, hence the name 'method adoption'. On the other hand, the availability of additional information, for example, access to a representative measure of business performance, as occurs with other methods, is not necessary.

Thus, while it is true that complementarity between variables implies the existence of a positive correlation between the two, the opposite does not have to apply, i.e. the existence of a positive correlation between variables does not necessarily mean that there is complementarity between the variables correlated. This is because, in the estimation of the corresponding correlation coefficients, selection bias and unobserved heterogeneity can take place. As a result of these problems, the correlation coefficients between variables are often used as an indication of the absence/ presence of complementarity; that is, the method helps to determine whether there is coexistence, substitutability or independence between the analysed variables. Consequently, this methodology allows us to obtain information on the degree of coexistence between the variables analysed, which is why some authors describe this method as analysis of coexistence (e.g. Vega-Jurado, GutiérrezGracia, \& Fernández-de-Lucio, 2009; GuisadoGonzález et al., 2013) . It is then possible to see how the adoption approach works by a simple example involving two activities.

It is assumed that there are two activities $A_{1}$ and $A_{2}$. Each activity can take the value 0 or 1 ; the first value indicates that the company under analysis has not adopted this activity, and the second value that the company has adopted it. Therefore, the adoption approach indicates that there will be correlation between the two variables if both covary positively, i.e.:

$$
\text { If, } \operatorname{Cov}\left(A_{1}, A_{2}\right)>0
$$

Nonetheless, there can be unobserved factors in the analysis which affect the covariance, which will result in a positive covariance despite the absence of coexistence between the activities concerned. In other cases, as indicated by Athey and Stern (1998), these factors can cause the existence of a negative covariance, and the undertaken activities really coexist. Therefore, with the aim of refining the assessment of coexistence and controlling the unobserved factors, Arora and Gambardella (1990) propose introducing in the analysis an exogenous variables vector, $Z_{i}$, which may influence the adoption of activities. The method proposed by these authors is to regress activities (considered in non-exclusive categories) over all the exogenous variables $Z_{i}$, to determine the corresponding regression errors and compute the covariance of these 
errors. If the covariance is positive, it is assumed that activities are coexistent; if the covariance is negative, it is assumed that the undertaken activities are substitutes. Obviously, it is also assumed that the expected value of the residuals is zero and its variance is equal to unity. From a formal point of view, the analysis model can be presented as follows $s^{\text {iii: }}$

$$
\begin{gathered}
A_{1}{ }^{i^{*}}=\alpha_{1} Z_{i}+\epsilon_{1}{ }^{i} \\
A_{2}{ }^{i^{*}}=\alpha_{2} Z_{i}+\epsilon_{2}{ }^{i} \\
E\left(\epsilon_{1}\right)=E\left(\epsilon_{2}\right)=0, \quad \operatorname{Var}\left(\epsilon_{1}\right)=\operatorname{Var}\left(\epsilon_{2}\right)=1
\end{gathered}
$$

if $\operatorname{Cov}\left(\epsilon_{1}, \epsilon_{2}\right)>0, A_{1}$ y $A_{2}$ are activities that coexist

if $\operatorname{Cov}\left(\epsilon_{1}, \epsilon_{2}\right)<0, A_{1}$ y $A_{2}$ are substitute activities.

\section{Data, variables and methodology}

The data used in the analysis were from the database of Technological Innovation Panel of 2008 (PITEC, 2008), developed by the National Statistics Institute of Spain (INE) under the guidelines of the Oslo Manual. The sample consists of a total of 12,813 companies, of which 311 are part of the tourism sector ${ }^{\text {iv }}$ and 99 are innovative companies in the tourism sector. Furthermore, the manufacturing sector consists of 5801 companies, of which 4844 are innovative manufacturers. In this regard, to be considered as innovative, the company must be active in one or more of the following activities of innovation: product innovation, process innovation, innovation underway or unsuccessful innovation.

The definition of the variables used in the empirical study is:

EIN. If the company is innovative, 1 . If it is not innovative, 0.

LNSIZE. Neperian logarithm of the number of employees of the company.

MDOLOCAL. If the company operates in the local market, 1 . If it does not operate in the local market, 0 .

MDONAT. If the company operates in the domestic market 1 . If it does not operate in the domestic market, 0 .

MDOINTERN. If the company operates in the international market, 1 . If it does not operate in the international market, 0 .
GROUP. If the company belongs to a group of companies, 1 . If it does not belong to a group of companies, 0 .

FACTCOST. The companies were asked to rate the importance that they attribute to several factors that hampered their innovation activities through a scale that ranges from 1 (not important) to 4 (very important). In the socalled 'cost factors', information was collected from firms regarding three factors: internal financial funding shortages; external financial funding shortages; and high innovation costs. The variable FATCOST collects the arithmetic mean of the three factors cited for each company.

FACTKNOW. This variable is defined identically to the above. The knowledge factors on which the information was collected were: lack of qualified personnel; lack of information regarding technology; lack of market information; and difficulties in finding partners for cooperation in innovation.

FACTMARK. Defined as identical to the previous mode. The market factors on which information was collected were: market dominated by established companies; and uncertainty over demand of innovative goods and services.

FACTNOINN. Defined as identical to the previous mode. In this case, firms were asked about two reasons for not innovating: that the company introduced previous innovations and the lack of demand for innovations.

ITO. Industrial technological opportunities evaluated from the information technology obtained from the company or the group of companies to which it belongs, suppliers, customers, competitors, attending trade fairs and business associations. The measurement scale of each source is identical to the factors previously defined. The final value of the variable is the arithmetic mean of the six sources indicated.

NITO. Non-industrial technological opportunities evaluated from the technological information obtained from consultants, universities, public research organisations, technology centres and scientific and technical journals. It is calculated identically to the previous variable.

INNPROD. If the company innovates in product, 1 . If it does not innovate in product, 0 . 
INNPROC. If the company innovates in process, 1 . If it does not innovate in process, 0 .

The objective of the current work is to calculate the correlation coefficients between two variables: product innovation and process innovation. Notwithstanding, as previously noted, if this calculation is performed on the observed values, the influences of exogenous variables may distort the reliability of the results. Therefore, and in order to correct these influences, Arora and Gambardella (1990) propose to regress each variable on a set of external variables that can influence its adoption. From these regressions are extracted the corresponding residuals and enable determination of the corresponding correlation coefficients.

It is necessary to add a step to the procedure proposed by Arora and Gambardella (1990), since the regressions analysed only make sense if they are performed by the group of innovative companies (EIN), because only these companies can innovate in terms of product and/or process. However, a focus only on innovative companies can result in the appearance of selection bias, because the sample was not randomly selected. In econometrics, this potential problem has been corrected by the Heckman correction (1979), which is applicable when the dependent variable is continuous. Since, in the present study, the two dichotomous variables are dependent, a similar procedure is used to that proposed by Manning, Duan and Rogers (1987), consisting of making a two-stage regression using the selection equation and the interest equation:

1. With the selection equation, a binary logistic regression is performed on the entire sample in this case, on the 311 tourism businesses and the 5801 manufacturing companies. The dependent variable will be the innovative companies (EIN) and the various independent variables will be a set of variables that influence the probability of being an innovator ${ }^{v}$. Of the two regressions performed, the predicted probability (PROB) of each company to become an innovative company is extracted.

2. In the second step, the probability of being an innovative company (PROB), calculated in the previous stage, is added to the set of independent variables in the equation of interest. Then a binary logistic regression is performed on the 99 innovative companies from the tourism sector and on the 4844 innovative companies from the manufacturing sector using, respectively, INNPROC and INNPROD as dependent variables.

It is possible to control selection bias with this procedure, since, in the equation of interest, the effects of non-innovative companies are included.

The equation of interest - from which are extracted the residuals used to calculate the corresponding correlation coefficient - attempts to determine the probability of innovation in product and process, respectively. Therefore, the independent variables must have an influence on such a probability. To this end, the variable LNSIZE is included, because most studies have found that size is a significant variable for explaining both types of innovation (e.g. Baldwin et al., 2002; Fritsch \& Meschede, 2001; Gopalakrishnan \& Damanpour, 2000; Jacob \& Groizard, 2007; Martínez-Ros, 2000; Sundbo et al., 2007). In addition, technological opportunities are incorporated, those derived both from the industry itself (ITO) and from outside the industry (NITO) since there are many studies that are relevant to technological opportunities in the analysis of innovation activities(e.g. Baldwin et al., 2002; Cabagnols \& Le Bas, 2002; Howells, Gagliardi, \& Malik, 2008; Lunn, 1986, 1987; Martinez-Ros, 2000; Meisel \& Lin, 1983; Tidd, Bessant, \& Pavitt, 2001; Vega-Jurado et al., 2008).

Finally, three variables are included related to the competitive intensity of the business MDOLOCAL, MDONAT and MDOINTERN which determine the company's presence in the local, national and international markets, respectively. There are studies that link a positive association between high competitive intensity and a higher propensity to innovate at product and process level (e.g. Baldwin et al., 2002; Bertschek, 1995). Other studies indicate that less competitive markets (with higher concentration) favour process innovations more than product innovations (Cohen \& keppler, 1996; Scherer, 1983). In any case, whether 
Testing the relationship between product innovation and process innovation. A comparative analysis of tourism and manufacturing sectors.

positive or negative associations, the literature expects the existence of a strong relationship between competitive intensity and product and process innovations.

The two binary logistic regressions provide us with the residuals that allow us to calculate the corresponding correlation coefficients. Such regressions, which are the equations of interest, are as follows:

INNPROD $=f($ LNSIZE, MDOLOCAL, MDONAT, MDOINTERN, ITO, NITO, PROB) INNPROC $=f(L N S I Z E$, MDOLOCAL, MDONAT, MDOINTERN, ITO, NITO, PROB)

\section{Results and discussion}

Innovative companies in the tourism sector accounted for $31.8 \%$ of all enterprises in the sector, while manufacturing innovation accounted for $83.5 \%$. By contrast, according to the descriptive statistics in Tables 1 and 2, the average size of innovative tourism enterprises is 931.42 employees, while in innovative manufacturing firms, the average only amounts to 173.43 employees for each company. Consequently, although the percentage of tourism enterprises which innovate is much lower, it is worth noting that those which innovate are much larger than the industrial companies that innovate.
Another big difference between both sectors concerns competitive intensity. Thus, it is found that $44 \%$ of innovative tourism companies compete in international markets, while for innovative manufacturing companies, this figure reaches $82 \%$. The specific peculiarity of the tourism product can help explain this remarkable difference.

Moreover, the average of the technological opportunities that tourism companies claim to have is lower than the observed average of the innovative manufacturing companies, mainly those of non-industrial origin (universities, public research organisations, etc.). This is an indication that traditionally the public resources in the R\&D (research and development) field were preferentially allocated to the industrial sector, not paying due attention to a sector like tourism, which generated $10.2 \%$ of Spanish GDP in 2010 (INE, 2011). Also, if Spain wants to continue leading the global tourism sector, it is necessary to incorporate new products and processes into its traditional tourism offer, since the classic product, beach and sun, may have reached a maximum level of exploitation. The cooperation of tourism enterprises with the Spanish public scientific structure can be an invaluable aid to the sector.

Finally, it is noted that the innovative tourist

Table 1. Descriptive statistics of innovative companies in the tourism sector

\begin{tabular}{cccccc}
\hline Variables & $\begin{array}{c}\text { No. of } \\
\text { observations }\end{array}$ & Minimum & Maximum & Mean & $\begin{array}{c}\text { Standard } \\
\text { deviation }\end{array}$ \\
\hline SIZE & 99 & 1 & 8225 & 931.42 & 1912.16 \\
MDOLOCAL & 99 & 0 & 1 & 0.86 & 0.35 \\
MDONAT & 99 & 0 & 1 & 0.77 & 0.42 \\
MDOINTERN & 99 & 0 & 1 & 0.44 & 0.50 \\
OTI & 99 & 1 & 3 & 2.06 & 0.72 \\
NITO & 99 & 1 & 1 & 1.41 & 0.53 \\
INNPROD & 99 & 0 & 1 & 0.36 & 0.48 \\
INNPROC & 99 & 0 & 0.80 & 0.40 \\
\hline
\end{tabular}

Table 2. Descriptive statistics of innovative companies in the manufacturing sector

\begin{tabular}{|c|c|c|c|c|c|}
\hline Variables & No. of observations & Minimum & Maximum & Mean & $\begin{array}{l}\text { Standard } \\
\text { deviation }\end{array}$ \\
\hline SIZE & 4844 & 1 & 10238 & 173.43 & 496.73 \\
\hline MDOLOCAL & 4844 & 0 & 1 & 0.95 & 0.21 \\
\hline MDONAT & 4844 & 0 & 1 & 0.96 & 0.20 \\
\hline MDOINTERN & 4844 & 0 & 1 & 0.82 & 0.38 \\
\hline OTI & 4844 & 1 & 4 & 2.44 & 0.70 \\
\hline NITO & 4844 & 1 & 4 & 1.82 & 0.72 \\
\hline INNPROD & 4844 & 0 & 1 & 0.72 & 0.45 \\
\hline INNPROC & 4844 & 0 & 1 & 0.73 & 0.45 \\
\hline
\end{tabular}


Table 3. Impact on turnover of goods or services which are new to the market

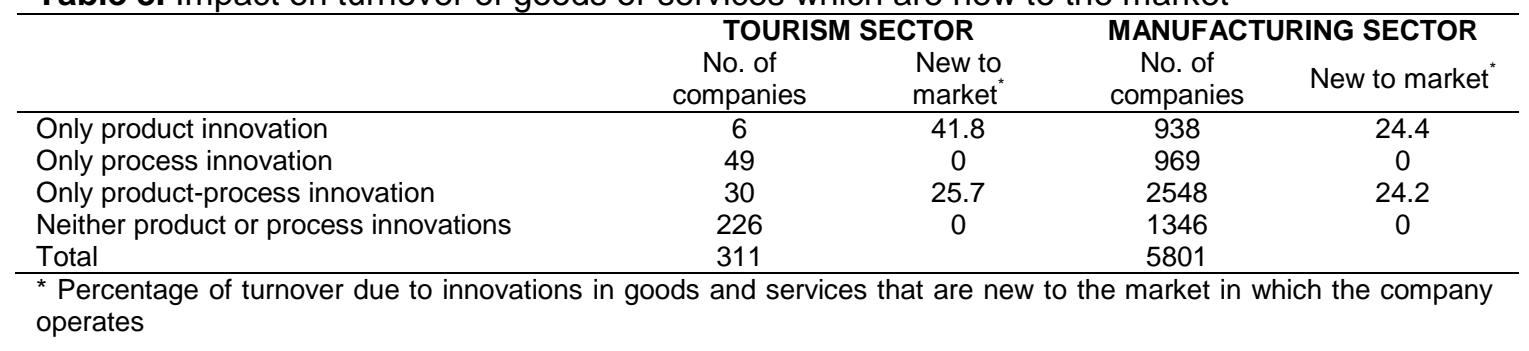

Table 4. Regression model results

\begin{tabular}{|c|c|c|c|c|}
\hline & \multicolumn{2}{|c|}{ TOURISM SECTOR } & \multicolumn{2}{|c|}{ MANUFACTURING SECTOR } \\
\hline & Product Innovation & Process Innovation & Product Innovation & Process Innovation \\
\hline \multirow[t]{2}{*}{ LNSIZE } & 0.156 & 0.019 & -0.011 & $0.250^{\star \star \star}$ \\
\hline & $(0.134)$ & $(0.152)$ & $(0.026)$ & $(0.027)$ \\
\hline \multirow[t]{2}{*}{ MDOLOCAL } & 0.225 & 1.206 & -0.085 & 0.112 \\
\hline & $(0.767)$ & $(0.888)$ & $(0.158)$ & $(0.153)$ \\
\hline \multirow[t]{2}{*}{ MDONAT } & -0.116 & 0.512 & -.0256 & 0.137 \\
\hline & $(0.635)$ & $(0.667)$ & $(0.171)$ & $(0.165)$ \\
\hline \multirow[t]{2}{*}{ MDOINTERN } & 0.772 & 0.148 & -0.157 & 0.088 \\
\hline & $(0.518)$ & $(0.645)$ & $(0.102)$ & $(0.100)$ \\
\hline \multirow[t]{2}{*}{ ITO } & -0.504 & $0.974^{*}$ & $0.821^{* * *}$ & $0.432^{\star * *}$ \\
\hline & $(0.400)$ & $(0.523)$ & $(0.061)$ & $(0.059)$ \\
\hline \multirow[t]{2}{*}{ NITO } & $1.114^{* *}$ & -0.404 & -0.091 & 0.074 \\
\hline & $(0.512)$ & $(0.605)$ & $(0.061)$ & $(0.059)$ \\
\hline \multirow[t]{2}{*}{ PROB } & 1.100 & 2.474 & $2.785^{\star \star \star}$ & $-0.964^{\star *}$ \\
\hline & $(1.478)$ & $(1.857)$ & $(0.320)$ & $(0.327)$ \\
\hline \multirow[t]{2}{*}{ CONSTANT } & $-2.884^{*}$ & -2.464 & $-2.706^{\star \star *}$ & $-0.669^{\star *}$ \\
\hline & (1.492) & (1.668) & $(0.292)$ & $(0.290)$ \\
\hline Number of cases & 99 & 99 & 4844 & 4844 \\
\hline $\begin{array}{l}\text { Percentage of } \\
\text { correct cases }\end{array}$ & 70.70 & 83.80 & 72.50 & 72.30 \\
\hline $\begin{array}{l}\text { Nagelkerke R- } \\
\text { Square }\end{array}$ & 0.147 & 0.167 & 0.128 & 0.062 \\
\hline
\end{tabular}

Notes: Standard errors are in parentheses; Statistical significance of the coefficients at ${ }^{* * *} 1 \%,{ }^{* *} 5 \%$ and ${ }^{*} 10 \%$

Table 5. Correlation coefficients of residues from product innovation and process innovation

\begin{tabular}{ccc}
\hline SECTOR & Correlation coefficient & Statistical Significance \\
\hline TOURISM & 0.092 & 0.363 \\
MANUFACTURING & 0.050 & 0.737 \\
\hline
\end{tabular}

companies are much less active than their industrial counterparts in terms of products, although they exhibit a slightly higher activity in process innovations. Again, the above asymmetry seems to demand more and more active collaboration between public R\&D and tourism enterprises in order to expand, at the level of differentiation, the supply of tourism products.

Moreover, by using the data in Table 3 , it is possible to achieve indiciary information on the existence of positive coexistence between product innovation and process innovation. Thus, the percentage impact on turnover (measured from sales of products or services that are a novelty for the market) of the combination of both types of innovation (product and process innovation) is lower than the impact from product innovation alone. This is an indication that both types of innovation are not positively correlated, though in order to formulate such a statement it is necessary to perform the test for coexistence.

Other evidence that betrays the impossible coexistence between product innovation and process innovation is reflected in the results obtained from the econometric estimation of the equation of interest. 
Testing the relationship between product innovation and process innovation. A comparative analysis of tourism and manufacturing sectors.

In Table 4, it can be seen that, in both the tourism and manufacturing sectors, the variables that significantly influence the probability of innovating at product and process level are not exactly the same. In the tourism sector, the non-industrial technological opportunities exhibit a positive and significant influence on the probability to innovate in the product, while the industrial technological opportunities influence the probability of innovating in the process. In the manufacturing sector, the industrial technological opportunities show a positive and significant influence on the probability to innovate in both types of innovation; however, the size of companies only has a positive and significant influence on the probability to innovate in the process while the PROB variable significantly influences both types of innovation, but with different signs.

Table 5 shows the result of the coexistence test that was conducted.

It was found that the correlation coefficients of both sectors, tourism and manufacturing, are weak, positive and non-significant. Therefore, it can be stated from a statistical perspective that both classes are neither alternatives nor coexistent, since both coefficients have a positive sign. It can be inferred that, since both kinds of innovation are independent, it is possible that the causes which put them into action are different. Such a conclusion would imply the absence of structural complementarities between the two types of innovation. Hence, at the level of product and process innovation, the results of the current study support the distinctive view versus the integrative view. That is, in this study it was not possible to find any evidence to support the integrative view, i.e. in both the tourism sector and the manufacturing sector, the findings are contrary to all positions that there is a clear relationship between product innovation and process innovation (Damanpour, 2010; Fritsch and Meschede, 2001, Pisano et al, 1997; Reichstein and Salter, 2006). Instead, the results support the so-called 'distinctive vision', which states that the causes of both types of innovation are different. This difference occurs because, while product innovation aims to generate or gain new markets, process innovation seeks to reduce delivery times and the corresponding unit costs of existing products or services (Knight, 1967; MartínezRos, 2000; Schilling, 2005).

\section{Conclusions}

The purpose of this paper is twofold: first, to determine whether in tourism the relations between product and process innovation are coexistence, substitution or independence, and second, to check whether these relationships are different from those that occur in the manufacturing sector, a view that is usually held by many authors, given the peculiarities of the tourism product.

The results obtained indicate that, statistically, product and process innovations in the tourism sector are independent. Therefore, these results support the distinctive view between the two types of innovation against the integrative view which advocates that there are synergies between the two kinds of innovation, and so their effects must be analysed together.

Contrary to the widely-held belief, the results reveal that the independence of both types of innovation is not an anomaly in the tourism sector, given its peculiarities, but also in the manufacturing sector both types of innovation are mutually independent.

These findings have obvious implications for scholars, management and policy makers. The results show that academic research efforts on product innovation and process innovation should be directed separately to the detection of the determinants of each of these types of innovation. Most of the existing literature on innovation supports this line of research (distinctive view), noting that product innovation depends heavily on R\&D activities previously performed (Hervas-Oliver et al, 2011.; Huang et al, 2010;. Rouvinen, 2002) while process innovation is more related to activities other than R\&D (Huang et al, 2010; Barge-Gil et al, 2011; Rouvinen, 2002). This view is particularly important in research on tourism, where expenditure on R\&D does not have the same importance as in manufacturing firms.

In addition, from the management perspective, the findings support the view that it is not necessary to carry out joint implementation of 
both types of innovation, as suggested by the integrative vision, since the determinants of both types of innovation are different. In short, implementation of a type of innovation does not imply the need to simultaneously implement the other, since both types of innovation are not complementary.

Further, the finding that there is no clear relationship between product innovation and process innovation gives policy makers a greater margin of manoeuvre in designing policies to promote innovation, and enables such policies to fit with structural conditions in the productive structure of each country. In countries where a production structure oriented towards competition in differentiation prevails, the implementation of policies that encourage activities that influence new product development (R\&D, mainly) should not be distorted by the promotion of such other activities that are key to the development of process innovations (mainly organisational innovations). These latter activities act as drivers of the cost competition strategy. It does not seem appropriate that policy makers implement public policies aimed at promoting the development of product innovations and process simultaneously, as each type of innovation has different drivers.

In relation to limitations of this study, it is necessary to be extremely careful about generalising these findings, because it must be taken into account that they have been obtained using data of the Spanish economy, which is characterised by a manufacturing sector with intermediate technological intensity. In other countries where more complex and technologically advanced manufacturing sectors exist, the results could be different.

For future studies, it would be useful to carry out a similar analysis based on countries that occupy a prominent place in the development of tourism, and whose production system uses, in general, more advanced technologies than the Spanish manufacturing sector. Furthermore, these studies could directly assess the relationship between product innovation and process innovation, implementing the econometric strategy and testing what Milgrom and Roberts (1990) have proposed in relation to this issue.

Finally, it should be emphasised that the Spanish tourism industry exhibits a lower innovative activity than industry, relies less on the technological opportunities available, probably because of the existence of a smaller supply available, and, on average, its innovative firms innovate more in processes than manufacturing firms, but far less than the latter at the product level.

\section{Endnotes:}

\footnotetext{
' Obviously, the existence of complementarity between different strategic options involves the coexistence thereof. But the relationship is not necessarily biunivocal, since the coexistence does not always imply the presence of complementarity.

ii In the manufacturing sector, most process innovations occur inside factories, away from the watchful eye of suppliers, customers and competitors. Therefore, such innovations are better protected in the manufacturing sector than in the tourism sector.

iii For reasons of expositive clarity, only two activities are considered here. If the number of activities were greater, the regression of each activity on the vector of characteristic variables, which influence the adoption of activities, should not be done separately, since, in general, the adopted activities are not independent of each other. If independent estimates are carried out, the estimates can be inefficient. For this reason, if, for example, the variable representing the activities is dichotomous $(0.1)$, it is necessary to define a polytomous variable which represents all activities, and proceed to the estimation of the parameters through the implementation of a multinomial logistic regression.

iv The database PITEC is not specifically designed to collect the innovative activity in the tourism sector. This database contains two classifications explicitly and separately, and both collect the vast majority of tourism activities: 'hospitality' and 'activities related to transportation'. There are other minor tourism activities that are grouped with non-tourist activities, but the level of detail in the database does not allow their separation.

${ }^{v}$ In the current study, similar or identical variables to other studies were included that have analysed the probability of being an innovator. To this end, included as explanatory variables, are: LNSIZE, MDOLOCAL, MDONAT, MDOINTERN, GROUP, FACTCOST, FACTKNOW, FACTMARK and FACTNINN. As the manufacturing sector consists of many sub-sectors, it is necessary to control their influence on the probability to innovate. For this purpose, a set of dummy variables associated with membership in each of the corresponding subsectors are included as explanatory variables.
} 


\section{References}

Abernathy, W. J., \& Utterback, J. M. (1978). Patterns of industrial innovation. Technology Review, 80, 40-47.

Adegbesan, J. (2009). On the origins of competitive advantage: Strategic factor markets and heterogeneous resource complementarity. Academy of Management Review, 34, 463-475.

Aldebert, B., Dang, R.J., \& Longhi, C. (2011). Innovation in the tourism industry: The case of Tourism. Tourism Management, 32(5), 1204-1213.

Alsos, G.A., Eide, D., \& Madsen, E.L. (2014). Introduction: innovation in tourism industries. In Alsos, Eide, Madsen (eds), Handbook of research in tourism industries, Edward Edgar Publising.

Arora, A., \& Gambardella, A. (1990): Complementarity and external linkages: the strategies of the large firms in biotechnology. Journal of Industrial Economics, 38(4), 361-379.

Athey, S., \& Stern, S. (1998): An empirical framework for testing theories about complementarity in organizational design. NBER Working Paper No. 6600 , Cambridge, MA.

Atuahene-Gima, K. (1996). Market orientation and innovation. Journal of Business Research 35, 93-103.

Baer, M., \& Frese, M. (2003). Innovation is not enough: Climates for initiative and psychological safety, process innovations, and girm performance. Journal of Organisational Behavior, 24, 45-68.

Baldwin, J., Hanel, P., \& Sabourin, D. (2002). Determinants of innovative activity in Canadian manufacturing firms. In A. Kleinknecht and P. Mohnen (eds), Innovation and Firm Performance, pp. 86-111. New York: Palgrave.

Baptista, R., \& Swann, P. (1998). Do firms in cluster innóvate more? Research Policy, 27, 525-540.

Barge-Gil A., Nieto M. J., Santamaría L. (2011). Hidden innovators: The role of nonR\&D activities. Technology Analysis \& Strategic Management, 23(4), 415-432.

Barney, J.B. (1991). Firm resources and sustained competitive advantage.
Journal of Management, 17(1), 99120.

Bertschek, I. (1995). Product and process innovation as a response to increasing imports and foreign direct investment. Journal of Industrial Economics, 43, 341-357.

Bhoovaraghavan, S., Vasudevan, A., \& Chandran, R. (1996). Resolving the process vs. product innovation dilemma: a consumer choice theoretic approach. Management Science, 42, 232-246.

Cabagnols, A., \& Le Bas, C. (2002). Differences in the determinants of product and process innovations: the French case. In A. Kleinknecht and P. Mohnen (eds), Innovation and Firm Performance, pp. 112-149. New York: Palgrave.

Camisón, C., \& Monfort-Mir, V.M. (2012). Measuring innovation in tourism from the Schumpeterian and the dynamiccapabilities perspectiva. Tourism Management, 33, 776-789.

Carvalho, L. (2011). Market structures, strategy and innovation in services. A study applied to the tourism sector. CEFAGEUE Working Paper 2011/27, Universidade de Évora, Portugal.

Cassiman, B., \& Veugelers, R. (2006). In search of complementarity in innovation strategy: Internal $R \& D$ and external knowledge acquisition. Management Science, 52(1), 68-82.

Cohen, W. M., \& Klepper. S. (1996). Size and the nature of innovation within industries: the case of process and product R\&D. Review of Economics and Statistics, 78, 232-243.

Cohen, W.M., \& Levinthal, D.A. (1989). Innovation and learning: the two faces of R\&D. Economic Journal, 99, 569596.

Cohen, W.M., \& Levinthal, D. A. (1990). Absorptive capacity: a new perspective on learning and innovation. Administrative Science Quarterly, 35(1), 128-152.

Conner, K. (1991). A historical comparison of resource-based theory and five schools of thought within industrial organization 
economics: Do we have a new theory of the firm. Journal of Management, 17(1), 121-154.

Damanpour, F. (2010). An Integration of Research Findings of Effects of Firm Size and Market Competition on Product and Process Innovations. British Journal of Management, 21, 996-1010.

Damanpour, F., \& Gopalakrishnan, S. (2001). The dynamics of the adoption of product and process innovations in organizations. Journal of Management Studies, 38, 45-65.

Drejer, I. (2004). Identifying innovation in surveys of services: a schumperian perspective. Research Policy, 33(3), 551-562.

Ettlie, J. E., \& Rubenstein, A.H. (1987). Firm size and product innovation. Journal of Product Innovation Management, 4, 89-108.

Fagerberg, J. (2005). Innovation: a guide to the literature. In Fagerberg, J. et al. (eds.), The Oxford handbook of innovation. Oxford University Press, Oxford, 1-26.

Flikkema, M., Jansen, P., \& Van der Sluis, L. (2007). Identifying neo-shumpeterian innovation in service firms. Economics of Innovation and New Technology, 16(7), 541-558.

Fritsch, M., \& Meschede, M. (2001). Product innovation, process innovation, and size. Review of Industrial Organization, 19, 335-350.

Gopalakrishnan, S., \& Damanpour, F. (2000). The impact of organizational context on innovation adoption in commercial banks. IEEE Transactions on Engineering Management, 47, 14-25.

Gronroos, C. (1990). Service Management and marketing. Lexington, MA.

Guisado-González, M., Guisado-Tato, M., \& Sandoval-Pérez, $\quad$ A. (2011): Technological determinants of innovation performance in Spanish hospitality companies: an analysis of the coexistence of innovation strategies. The Services Industries Journal, 33(6), 580-593.

Gunday, G., Ulusoy, G., Kilic, K., \& Alpkan, L. (2011). Effects on innovation types on firm performance. International Journal of Production Economics, 133(2), 662 676.

Hagedoorn, J., \& Wang, N. (2012). Is there complementarity or substitutability between internal and external R\&D strategies? Research Policy, 41, 10721083.

Hall, C. M., \& Williams, A. M. (2008). Tourism and innovation. Routledge, London and New York.

Han, J.K., Kim, N., \& Srivastava, R.K. (1998). Market orientation and organisational performance: is innovation the missing link? Journal of Marketing, 62(4), 3045.

Heckman, J. (1979): Sample selection bias as a specification error. Econometrica, 47(1), 153-161.

Hervas-Oliver J. L., Albors Garrigos J., \& GilPechuan I. (2011). Making sense of innovation by R\&D and non-R\&D innovators in low technology contexts: A forgotten lesson for policymakers. Technovation, 31(9), 427-446.

Hitt, M.A., Ireland, R.D., Camp, S.M., \& Sexton, D.L. (2001). Guest editors' introduction to the special issue strategic entrepreneurship: entrepreneurial strategies for wealth creation. Strategic Management Journal, 22, 479-491.

Hjalager, A.M. (2002). Repairing innovation defectiveness in tourism. Tourism Management, 23(5), 465-474.

Hjalager, A.M. (2010). A review of innovation research in tourism. Tourism Management, 31, 1-12.

Hjalager, A.M. (2013). 100 innovations that transformed tourism. Journal of Travel Research (doi: 10.1177/0047287513516390).

Hollanders, H., \& Van Cruysen, A. (2008). Rethinking the European innovation scoreboard: A new methodology for 2008-2010. Maastricht: PRO INNO Europe INNO Metrics, UNU-MERIT, Maastricht Economic and Social Research and Training Centre on Innovation and Technology, Maastricht University.

Howells, J., Gagliardi, D., \& Malik, K. (2008). The Growth and Management of R\&D Ourtsourcing: Evidence from UK 
Pharmaceuticals. R\&D Management, 38, 205-219.

Huang C., Arundel A., Hollanders H. (2010). How firms innovate: $R \& D$, non- $R \& D$, and technology adoption. Working Paper Series, UNU-MERIT.

Hult, G.T., Snow, C.C., \& Kandemir, D. (2003). The role of entrepreneurship in building cultural competitiveness in different organizational types. Journal of Management, 29(3), 401-426.

INE (2011). Cuenta satélite del turismo de España. Base 2008. Madrid.

Ittner, C.D., \& Larcker, D.F. (1997). The performance effects of process management techniques. Management Science, 43, 522-534.

Ivanov, S.H. \& Webster, C. (2013). Tourism's contribution to economic growth: a global analysis for the first decade of the millennium. Tourism Economics, 19(3), 477-508.

Jacob, M., \& Groizard, J.L. (2007): Technology transfer and multinationals: The case of Balearic hotel chains'investments in two developing economies. Tourism Management, 28(4), 976-992.

Knight K. E. (1967). A descriptive model of the intra-firm innovation process. Journal of Business, 40(4), 478-496.

Knott, A.M. (2001). The dynamic value of hierarchy. Management Science, 47, 430-448.

Kraft, K. (1990). Are product- and processinnovations independent of each other? Applied Economics, 22, 1029-1038.

Li, H., \& Atuagene-Gima, K. (2001). Product innovation strategy and the performance of new technology ventures in China. Academy of Management Journal, 44(6), 11231134.

Lunn, J. (1986). An empirical analysis of process and product patenting: a simultaneous equation framework. Journal of Industrial Economics, 34, 319-330.

Lunn, J. (1987). An empirical analysis of firm process and product patenting. Applied Economics, 19, 743-751.

Manning, W.G., Duan, N., \& Rogers, W.H. (1987): Monte Carlo evidence on the choice between sample selection and two-part models. Journal of Econometrics, 35, 59-82.

Marcus, A.A. (1988). Responses to externally induced innovation: Their effects on organisational performance. Strategic Management Journal, 9, 387-402.

Martinez-Ros, E. (2000). Explaining the decisions to carry out product and process innovations: the Spanish case. Journal of High Technology Management Research, 10, 223-242.

Meisel, J. B., \& Lin, S.A.Y. (1983). The impact of market structure on the firm's allocation of resources to research and development. Quarterly Review of Economics and Business, 23, 28-43.

McAdam, R., \& Keogh, K. (2004). Transitioning towards creativity and innovation measurement in SMEs. Creativity and Innovation Management, 13(2), 126141.

Milgrom, P., \& Roberts, J. (1990): The economics of modern manufacturing: Technology, strategy, and organization. American Economic Review, 80, 511528.

Miller, D., \& Friesen, P. H. (1984): A longitudinal study of the corporate life cycle. Management Science, 30, 11611183.

Miller, D. (1986). Configurations of strategy and structure: Towards a synthesis. Strategic Management Journal, 7, 233249.

Narver, J.C., \& Slater, S.F. (1990). The Effect of a Market Orientation on Business Profitability. Journal of Marketing, 54, 20-35.

Olson, C.A., \& Schwab, A. (2000). The performance effects of human resource practices: the case of interclub networks in professional baseball, 1991-1940. Industrial Relations, 39, 553-577.

Pechlaner, H., Reuter, Ch., \& Zehrer, A. (2010). Innovation awards in the German Tourism Industry. In K. Weiermair, P. Keller, H. Pechlaner, \& F. Go (eds), Innovation and Entrepreneurship - Strategies and 
Processes for Success in Tourism, ESV Verlag, 81-96

Peteraf, M. A. (1993). The cornerstones of competitive advantage: A resourcebased view. Strategic Management Journal, 14, 170-181.

Pires, C., Sarkar, S., \& Carvalho, L. (2008). Innovation in services - how different from manufacturing? Service Industries Journal, 28(10), 1339-1356.

Pisano G., Shuen A., \& Teece D. (1997). Dynamic capabilities and strategic management. Strategic Management Journal, 18(7), 509-533.

Porter, M. E. (1985). Competitive Advantage: Creating and Sustaining Superior Performance. New York: Free Press.

Powell, T. C., \& Dent-Micallef, A. (1997). Information technology as competitive advantage: The role of human, business, and technology resources. Strategic Management Journal, 18, 375-405.

Reichstein T. \& Salter A. (2006). Investigating the sources of process innovation among UK manufacturing firms. Industrial and Corporate Change, 15(4), 653-682.

Rigby, D., \& Zook, C. (2002): Open-market innovation. Harvard Business Review, 80(10), 80-89.

Ritchie, J. R., \& Crouch, G.I. (2000). The competitive destination: A sustainability perspective. Tourism Management, 21(1), 1-7.

Rothwell, R., Freeman, C., Horsley, A., Jervis, V.T.P., Robertson, A.B., \& Townsend, J. (1974): Sappho updated: Project Sappho: Phase II. Research Policy, 3(3), 258-291.

Rothwell, R. (1975): Innovation and firm size: A case for dynamic complementarity; or, is small really so beautiful? Journal of General Management, 2, 5-25.

Rouvinen P. (2002). Characteristics of product and process innovators: Some evidence from the finnish innovation survey. Applied Economics Letters, 9(9), 575-580.

Salter, A., \& Alexy, O. (2014). The Nature of Innovation. In M. Dodgonson, D. Gann, \& N. Phillips (eds), The Oxford
Handbook of Innovation Management, Oxford University Press, 26-52.

Scherer, F. M. (1983). Concentration, productivity, and $R \& D$ change. Southern Economic Journal, 50, 221275.

Schilling, M. A. (2005). Strategic Management of Technological Innovation. New York: McGraw-Hill Irwin.

Schmiedeberg, C. (2008): Complementarities of innovation activities: An empirical analisis of the German manufacturing sector. Research Policy, 37, 14921503.

Shaw, G., \& Williams, A. (2009). Knowledge transfer and management in tourism organisations: An emerging research agenda. Tourism Management, 30, 325-335.

Somaya, D., Williamson, I. O., \& Zhang, X. (2007). Combining patent law expertise with R\&D for patenting performance. Organization Science, 18, 922-937.

Subramanian A., \& Nilakanta, S. (1996). Organisational innovativeness: Exploring the relationship between organisational determinants of innovation, types of innovations, and measures of organisational performance. Omega, 24(6), 631-647.

Sundbo, J. (2007). Innovation and Learning in Services. The Involvement of Employees. In D. Spath, \& K.P. Fähnrich, (eds.), Advances in services innovations. Springer, Berlin, Heidelberg, 131-150.

Sundbo, J., Orfila-Sintes, F., \& Sørensen, F. (2007). The innovative behaviour of tourism firms - comparative studies of Denmark and Spain. Research Policy, 36(1), 88-106.

Teece, D.J. (1986). Profiting from technological innovation: Implications for integration, collaboration, licensing and public policy. Research Policy, 15, 285-305.

Teece, D.J., Pisano, G., \& Shuen, A. (1997). Dynamic capabilities and strategic management. Strategic Management Journal, 18, 509-533.

Tether, B. S (2014). Services, Innovation and Managing Service Innovation. In M. Dodgonson, D. Gann, \& N. Phillips (eds), The Oxford Handbook of 

manufacturing sectors.

Innovation Management, Oxford University Press, 600-624.

Tether, B.S., \& Howells, J. (2007). Changing understanding of innovation in services: from technological adoption to complex complementary changes to technologies, skills and organisation. DTI Occasional Paper No. 9, June, 2160.

Tidd, J., Bessant, J., \& Pavitt, K. (2001). Managing Innovation: Integrating Technology, Market, and Organizational Change. New York: Wiley.

Topkis, D. L. (1978): Minimizing a submodular function on a lattice. Operations Research, 26, 305-321.

Vega-Jurado, J., Gutiérrez-Gracia, A., \& Fernández-de-Lucio, I. (2009): La relación entre las estrategias de innovación: Coexistencia o complementariedad. Journal of Technology Management \& Innovation, 4(3), 74-88.

Vives, X. (1990): Nash Equilibrium with strategic complementarities. Journal of Mathematical Economics, 19(3), 305321.

Volo, S. (2004), Foundation for an innovation indicator for tourism. In Keller, P., Bieger, T. (eds.), The future of small and medium sized enterprises in tourism. AIEST, St. Gallen, 361-376.

Walker, R. M. (2004). Innovation and organizational performance: evidence and a research agenda. AIM Research Working Paper, Advanced Institute for Management Research, London.
Weiermair, K. (2006). Product improvement or innovation: what is the key to success in tourism? In OECD, Innovation and growth in tourism. OECD, Paris, 53-69.

Weiermair, K., \& Peters, M. (2002). Innovation behaviour in hospitality and tourism: Problems and Prospects. In Tourism in Asia: Development, Marketing and Sustainability. Fifth Biennial Conference, Hong Kong Polytechnic University, Hong Kong.

Wernerfelt, B. (1984). A resource-based view of the firm. Strategic Management Journal, 5(2), 171-180.

Whittington, R., Pettigrew, A., Peck, S., Fenton, E., \& Conyon, M. (1999). Change and complementarities in the new competitive landscape: A European panel study, 1992-1996. Organisation Science, 10, 583-600.

Williams, A.M. (2014). Tourism innovation: products, processes and people. In C.M. Hall, A.M. Williams, \& A.A. Lew (eds), The Wiley Blackwell Companion to Tourism, John Wiley, 168-178.

WTO. (2012). International tourism receipts surpass US\$ 1 trillion in 2011. PR No.: PR 12027, May, Madrid.

Zahra, S.A., \& George, G. (2002). Absortive Capacity: a review, reconceptualization and extension. Academy of Management Review, 27(2), 185-203.

Zahra, S. A., Neubaum, D.O., \& Huse, M. (2000). Entrepreneurship in mediumsize companies: exploring the effects of ownership and governance systems. Journal of Management, 26(5), 947976. 